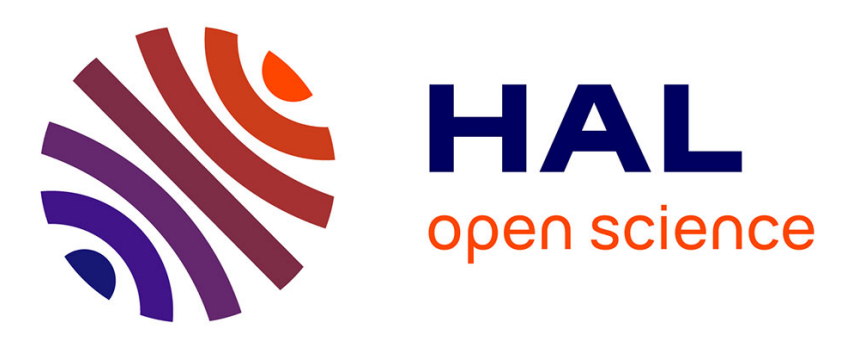

\title{
Can the emergence of pine Diplodia shoot blight in France be explained by changes in pathogen pressure linked to climate change?
}

Bénédicte Fabre, Dominique Piou, Marie-Laure Desprez-Loustau, Benoit Marçais

\section{To cite this version:}

Bénédicte Fabre, Dominique Piou, Marie-Laure Desprez-Loustau, Benoit Marçais. Can the emergence of pine Diplodia shoot blight in France be explained by changes in pathogen pressure linked to climate change?. Global Change Biology, 2011, 17 (10), pp.3218-3227. 10.1111/j.1365-2486.2011.02428.x . hal-02113636

\section{HAL Id: hal-02113636 \\ https://hal.science/hal-02113636}

Submitted on 29 Apr 2019

HAL is a multi-disciplinary open access archive for the deposit and dissemination of scientific research documents, whether they are published or not. The documents may come from teaching and research institutions in France or abroad, or from public or private research centers.
L'archive ouverte pluridisciplinaire $\mathbf{H A L}$, est destinée au dépôt et à la diffusion de documents scientifiques de niveau recherche, publiés ou non, émanant des établissements d'enseignement et de recherche français ou étrangers, des laboratoires publics ou privés. 


\title{
Can the emergence of pine Diplodia shoot blight in France be explained by changes in pathogen pressure linked to climate change?
}

\author{
Bénédicte Fabre ${ }^{1}$, Dominique Piou ${ }^{2}$, Marie-Laure Desprez-Loustau ${ }^{3}$ and Benoît Marçais ${ }^{1}$ \\ ${ }^{1}$ UMR1136 Interactions Arbres-Microorganismes, INRA-Nancy, F-54280, Champenoux, \\ France; \\ ${ }^{2}$ Département de la Santé des Forêts, Pierroton, F-33612 Cestas, France \\ ${ }^{3}$ UMR1202 BioGeCo, Pathologie Forestière, INRA, F-33612 Cestas, France
}

Corresponding author: Benoît Marçais, Tel.: +33 383394053, Fax: +33 383394069, Email: marcais@inra.nancy.fr

Key words: Diplodia pinea, Diplodia scrobiculata, pine, global change, climate warming, disease emergence.

\section{Summary}

Sphaeropsis shoot blight, caused by Diplodia pinea and D. scrobiculata, damage conifers throughout the world. In France, the first disease outbreaks were reported during the $90^{\text {ies }}$. The factors associated with the pathogen presence in stands and the relationship between pathogen and disease distributions were analysed in order to understand the Sphaeropsis emergence. Eighty two stands of Pinus nigra, $P$. sylvestris, $P$. pinaster and $P$. radiata were visited. Cones were collected on the ground to assess the pathogen frequency. Diplodia spp were isolated and determined by a species-specific PCR test. The role of potential explaining factors of $D$. pinea prevalence on cones was analysed by logistic regression. $D$. pinea was the dominant species in visited stands. The main factors influencing the pathogen presence selected in the models were host species (the pathogen being less frequent on $P$. pinaster than on $P$. nigra and $P$. sylvestris cones), winter temperature and summer rain, which were both positively correlated with cone colonization. The climate became more favourable to $D$. pinea presence within the last 15 years compared to the previous 30-year period. By contrast, future climatic changes over the next 40 years should have far less impact on the pathogen presence.

\section{Introduction}

Emerging plant diseases, i.e. diseases that either increase in geographical or host range or in severity within their range, are a major issue throughout the world (Harvell et al., 2002, Anderson et al., 2004). Among several causes reported to influence disease emergence, climate change and the introduction of pathogens in new areas linked to the increase in international trade are very important (Anderson et al., 2004, Desprez-Loustau et al., 2007, Sturrock et al., 2011). Several plant pathogens might have increased their range or severity due to improved environmental conditions for disease development (Garrett et al., 2006). Indeed, climate change affects host-pathogen interactions by either direct effects on pathogens or by modifying host physiology and resistance. Direct effect include increased 
pathogen multiplication during the vegetation season, for example increase in foliar pathogens such as Dothistroma septospora during warmer and moister springs (Woods et al, 2005), or increased pathogen survival in milder winters (Marçais et al, 1996). Indirect effects via altered host physiology include modification of host resistance in different temperature ranges such as in the wheat-Puccinia recondita system (Browder \& Eversmeyer, 1986) or increased host susceptibility after a drought (Blodgett et al, 1997, Desprez-Loustau et al. 2006). Disentangling the direct and indirect effects of climate change on a plant disease is often difficult because, as the pathogens are usually present only on affected hosts, it is difficult to determine whether an increased frequency is caused by climatic conditions more favourable to the pathogen multiplication or to an increased host susceptibility. While many studies on plant emerging diseases have dealt with the introductions of pathogens in a new area, the impacts of climate change on plant disease remains little documented so far (Garrett et al., 2006, Desprez-Loustau et al., 2007).

Sphaeropsis shoot blight is a good example of emerging disease where several factors could have promoted emergence. This disease, induced by Sphaeropsis sapinea (Fr.:Fr.) Dyko and Sutton (syn. Diplodia pinea (Desmaz.) J. Kickx fil.), causes serious damage on Pinus spp. throughout the world (Nicholls \& Ostry, 1990, de Kam, 1985, Burgess et al., 2004). In Europe, the disease was first reported as a major pine problem by de Kam in 1985. In France, severe Sphaeropsis sapinea-induced pine declines were reported for the first time in the early $90^{\text {ies }}$ on Pinus nigra and P. sylvestris (Piou et al., 1991). Although the pathogen had been present in France since at least the end of the $19^{\text {th }}$ century and was commonly observed on pines throughout the country in the 70ties by Morelet (1980) (under the name Macrophoma pinea), it was only reported as a minor pine disease (Lanier et al 1976). De Kam (1985) suggested that several factors could concur to the Sphaeropsis shoot blight emergence in Europe among which: (i) the replacement of the European native populations of $S$. sapinea by new populations or cryptic species of the pathogen, (ii) climate change that might influence both host susceptibility and pathogen presence or (iii) factors increasing the host susceptibility such as anthropogenic increase in nitrogen deposition.

A change in the pathogen population during the $20^{\text {th }}$ century could have been unnoticed since $S$. sapinea is a species complex. Three morphotypes (A, B and C) were described on the basis of cultural characteristics, isozyme patterns and conidial morphology (Palmer et al., 1987). Later, de Wet et al. (2003) showed that the B morphotype can be defined as a separate species, Diplodia scrobiculata, using multiple gene genealogies, while the $\mathrm{A}$ and $\mathrm{C}$ morphotype were merged in the $D$. pinea species. $D$. scrobiculata was shown to be less aggressive than D. pinea in inoculation trials (Palmer et al., 1987, Bihon et al., 2010). Hereafter, $S$. sapinea will refer to $S$. sapinea sensu lato. In France, all reports refer to $S$. sapinea sensu lato, but the two morphotypes A and B were reported on a Cedrus deodara in 1993 (Morelet \& Chandelier, 1993). The relative frequency of the two species on pines thus remains unknown.

Environmental changes are also a likely hypothesis to explain the emergence of Sphaeropsis shoot blight as disease outbreaks usually depend on the occurrence of particular conditions such as hail, drought or heat-wave (van Staden et al., 2004, Zwolinski et al., 1990). The reported increase in both summer temperature and drought frequency associated with climate change would thus presumably exacerbate the disease. Sphaeropsis shoot blight could be favoured both via direct effects on the pathogen and indirect effects via host susceptibility. Indeed, S. sapinea is a thermophilic species with an optimum temperature for growth near $30^{\circ} \mathrm{C}$ (Keen \& Smits 1989, Desprez-Loustau et al., 2007) and its growth rate should be favoured by climate warming. Indirect effects are also likely to be important as susceptibility of pines to $D$. pinea is strongly enhanced by water stress (Blodgett et al, 1997). Altered nitrogen nutrition can also promote the disease and Sphaeropsis shoot blight outbreaks in the Netherlands were related to anthropogenic nitrogen deposition (van Dijk et al., 1992; Stanosz et al., 2004). Sphaeropsis shoot blight is a good model to sort out direct effects of environmental changes on the pathogen from indirect effects on the host 
susceptibility as high levels of Sphaeropsis inoculum in the stands are not conditioned by a high disease severity but rather depend on the presence of infected cones. Indeed, $S$. sapinea readily colonizes pine cones and colonized cones are important sources of inoculum. Palmer et al. (1988) showed that abundance of inoculum from cones was of primary importance for disease development in red pines. However, S. sapinea can be heavily present even in stands not severely affected by Sphaeropsis shoot blight when conditions are not conducive to the disease (Palmer et al., 1988, Fecci et al., 2002, Munck \& Stanosz, 2010).

Our study was focused on possible qualitative and quantitative changes in the pathogen that might explain the emergence of $S$. sapinea disease in pines stands in France. We specifically addressed the following points: (i) determine the relative frequency of the two Diplodia species in a systematic survey of the presence of the fungi on pine cones, (ii) determine whether a relationship between the France-wide spatial pattern in S. sapinea inoculum availability on cones and disease regional frequency can be found; regional Sphaeropsis shoot blight frequency was estimated using data from the DSF, the French forest health survey agency, (iii) test whether the recent change in climate could have contributed to the emergence of the disease in France by favouring $S$. sapinea presence in the stands through directs effects on the pathogen. For that, we fitted a model linking climate variables to the frequency of the pathogen on pines cones and studied the response of past and predicted future changes of the climate on the pathogen abundance in the stands.

\section{Materials and methods}

\section{Plot selection and survey procedure for study of S. sapinea presence in pines stands}

Pines plots were surveyed for presence of $S$. sapinea by rating the frequency of the pathogens pycnidia on cones collected on the ground. The frequency of $S$. sapinea on cones was taken as a measure of inoculum presence in the stands. Plots were selected among the 509 plots of the French part of the level 1 ICP European network for monitoring of forest damage (permanent plots located on a $16 \times 16 \mathrm{~km}$ grid covering all of Europe). The stands are located with their GPS coordinates; position on a 1:25000 map and an orthophotography are available. In each plot, 20 contiguous trees, selected in the dominant strata were marked, determined to the species and have been surveyed annually since 1989 for crown condition. The sample is open, trees disappearing each year being replaced. We selected all the plots within this network which had at least four Pinus nigra, $P$. sylvestris and/or $P$. pinaster and trees over 20 year-old on which cone could be found (97 plots). The 51 plots with $P$. nigra and/or P. sylvestris were surveyed from June to November 2005 (12 P. nigra plots, 34 $P$. sylvestris plots, 1 plot with both $P$. pinaster and $P$. sylvestris and 2 with both $P$. nigra and $P$. sylvestris, see Fig. 1a). The 29 plots with $P$. pinaster were visited in January 2006. We also included in the survey four plots of $P$. radiata that did not belong to the level 1 ICP network and that were visited by the staff of the Département de la Santé des Forêts, one in Corsica, one in the Pyrenean piedmont and two in Brittany. They were treated as the other pine stands. Altogether, 194 P. nigra, 626 P. sylvestris, 40 P. radiata and 562 P. pinaster were rated.

In each selected plot, we sampled 10 cones on the soil at the base of 10 different pine trees in order to study the frequency of cone colonization by $S$. sapinea as a measure of the level of pathogen presence in the stand. The trees of the permanent plots $(P$. nigra, $P$. sylvestris, $P$. radiata and/or $P$. pinaster) were sampled in priority and additional neighbouring pines were sampled when needed. The sampled cones had been on the soil for about 1-3 years. Depending on the pine species, cones remains on the tree for 2 to 3 years before being shed. Thus the cone colonisation by $S$. sapinea was assumed to represent the average recent inoculum availability in the stand. After collection, the cones were put in paper bags and brought back to the laboratory for analysis. 


\section{Fungal isolations and species determinations}

Samples were air-dried in the laboratory at room temperature and then stored at $4^{\circ} \mathrm{C}$ until processed. S. sapinea produces black pycnidia on the top of the cone scales (Fecci et al., 2002). The presence of pycnidia was recorded for each cone by macroscopic examination. When pycnidia were present, conidia were examined to determine whether they corresponded to $S$. sapinea spores i.e. thick walled spores, hyaline to brown when mature, with $0-1$ septum.

Four cone scales with pycnidia were randomly chosen from each cone for a fungus isolation procedure adapted from Vujanovic et al. (2000). Each scale was surface sterilized i.e. placed in $70 \%$ ethyl alcohol for $10 \mathrm{~s}$, rinsed in sterile distilled water, put in $2.5 \%$ sodium hypochlorite for $1.5 \mathrm{~min}$, rinsed twice for $5 \mathrm{~min}$ in sterile distilled water and finally dried on sterile filter papers. Then, half of the scales was placed on Malt Agar (MA, Difco) and the other half on Potato Dextrose Agar (PDA, Difco). The plates were incubated at $25^{\circ} \mathrm{C}$ in the dark. Putative $S$. sapinea isolates, i.e. fast growing cultures visible after 4 days with aerial mycelium and grey to black colour, were then isolated in pure culture and transferred to PDA Petri dishes containing a sterilized pine needle and incubated at $25^{\circ} \mathrm{C}$ for 7 days in the dark and then about 10 days in the light. Cultures were determined to be $S$. sapinea when pycnidia with typical brown spores were produced on the needle.

A sub-sample of the $S$. sapinea sensu lato isolates was determined for species, i.e. Diplodia pinea or $D$. scrobiculata, by a species-specific polymerase chain reaction (PCR) test developed by Smith and Stanosz (2006). At least one isolate per cone was selected. If, based on morphology of the culture, isolates suspected of belonging to different Diplodia species were present on a cone, all the available isolates from the cone were determined for species. Blocks of agar were cut from culture collections and transferred to PDA Petri plates. Cultures were incubated at $25^{\circ} \mathrm{C}$ for 5 days. A rapid DNA extraction was done: non pigmented fungal mycelium from the active culture margin was scraped and put in $100 \mu \mathrm{l}$ of 10x Tris-EDTA buffer and was then incubated for $5 \mathrm{~min}$ at $98^{\circ} \mathrm{C}$ and put in ice for $3 \mathrm{~min}$; this sequence was repeated one time. The PCR reactions were performed as described by Smith and Stanosz (2006). All samples were tested for the presence of both D. pinea and $D$. scrobiculata using the respective specific primers DpF/BotR and DsF/BotR (Smith \& Stanosz, 2006). Negative and positive controls were always included i.e. no DNA, DNA from CMW190 for D. pinea and CMW4898 for D. scrobiculata (de Wet et al., 2003). The amplification reactions were carried out on a Genamp 9700 thermocycler (Applied Biosystems, Foster City, California).

\section{Model of S. sapinea prevalence on pine cones}

The prevalence of $S$. sapinea on cones, i.e. proportion of cones infected by the pathogen, was analyzed by logistic regression, using the GENMOD procedure of SAS/STAT 8.1 (SAS Institute, Cary, NC). This type of analysis assumes that the response variable follows a binomial distribution and that a function of the response (the link function) is linearly related to the independent variables (Collet, 1991). We used the Logit function as link function. Models were selected by a forward selection procedure, choosing at each step the variable that induced the largest drop in deviance.

Independent variables that might explain the frequency of $S$. sapinea on cones were stand characteristics such as pine species, age, stand origin (natural or planted), altitude and climate variables. The stands characteristics were provided by the Département de la Santé des Forêts (Nancy, France). Most natural stands were $P$. sylvestris in the mountain regions of Alps and Massif Central (20/31). However a limited number of natural stands occurred in plain areas (seven $P$. sylvestris, two $P$. nigra and two $P$. pinaster stands). Climate variables for each plot were taken from the nearest meteorological station of the Météo-France network with available data over the 1990-2005 period for monthly rain and average temperature (1244 stations in total). Average climate across a long 15 years period was 
chosen as inoculum on cones was assumed to better reflect long term Sphaeropsis presence in the stand. The median distance between the plot and the meteorological station was 9.9 $\mathrm{km}$ (range 1-20 km). The climatic variables tested were the means over the 1990-2005 period of minimum, maximum and mean daily temperatures, sum of precipitations (in $\mathrm{mm}$ ) and water balance (precipitation minus evapotranspiration, in $\mathrm{mm}$ ) for four periods, i.e. winter (December to February), spring (March to May), summer (June to August) and autumn (September to November).

\section{Estimation of the regional frequency of Sphaeropsis shoot blight}

The database of the Département de la Santé des Forêts (DSF) stores records of health problems detected in France by a network of foresters trained to diagnose all types of forest health affections, including abiotic, entomological or pathological damages. DSF observer report health problem that they judge significant, i.e. that disturb stand management or that is of unusual severity for the area. Altogether, from 1989 to 2006, about 12800 records of health problems on Pinus species were entered in the database, 1064 of which concerned Sphaeropsis shoot blight. This database was used as an estimate of the regional frequency of Sphaeropsis shoot blight in pine stands. The non-systematic and nonhomogeneous way used for data collection and the fact that only occurrence is recorded cause difficulties for the analysis of those data and does not allow the estimate of frequency of infected host. In particular, in order to interpret a local number of disease records, there is a need to estimate a local expected number of records that strongly depend on the local density of host and on the activity of the local people who produce the records. The methodology used was adapted from what is done in medical epidemiology (Lawson, 2001). Basically, the raw number of records of the studied disease is compared to the raw number of records for a set of problems selected to be typical of the host population of interest (the so-called 'at risk' population). The local density of reference records is considered to be an estimate of the at-risk population local surface and of the observation pressure by local observers. Reports on the 3 main hosts were used, $P$. nigra, $P$. pinaster and $P$. sylvestris. $P$. halepensis was not used because few $S$. sapinea reports have been made on that host (about 10). $P$. pinea and $P$. uncinata reports were not used although $S$. sapinea reports are significant on those hosts because those species are not well enough represented in the DSF database. We used as reference reports all non $S$. sapinea reports except reports on Thaumetopoea pityocampa and $D$. septospora that were very frequent and showed a strong spatial pattern. Altogether, 1019 S. sapinea reports and 7646 reference reports were used (Fig 2a).

All records from 1989 to 2006 were pooled to estimate average local disease severities. Local density of Sphaeropsis shoot blight and reference records were computed using nonparametric kernel estimation method (Wand \& John 1995). This method estimates the record density on each point of a grid. Each record is weighed by the kernel function according to the distance to the grid point. The bandwidth is the important kernel parameter controlling the weight decay with the distance to the grid point. We computed the records density for each point of a $10 \times 10 \mathrm{~km}$ grid. The quartic kernel with a bandwidth of $80 \mathrm{~km}$ was used for both Sphaeropsis shoot blight and reference records density. The least square cross-validation (Wand \& Jones, 1995) was used to estimate the values of the bandwidth on several portions of the surveyed area, and to choose one which was large enough to avoid cases lacking record within the discus defined by the bandwidth.

A standardized record rate (SRR) was produced by dividing the Sphaeropsis shoot blight records density by the reference record density. Therefore, an estimate of SRR for the 1989-96 period was computed for each point of the $10 \times 10 \mathrm{~km}$ grid. However, the report rate of Sphaeropsis shoot blight is very different on its different hosts $(P$. nigra, $P$. pinaster and $P$. sylvestris) and this had to be taken into account to avoid that the map merely shows the distribution of the most susceptible host. Therefore, records density of both Sphaeropsis 
shoot blight and the reference were computed for each host $(P$. nigra, $P$. pinaster and $P$. sylvestris) and the SRR for the disease was computed as:

$$
\mathrm{SRR}=\Sigma_{\text {host }}(\mathrm{SSB} \text { _report } \text { host }) / \Sigma_{\text {host }}\left(\text { Reference_report }_{\text {host }} \mathrm{x} \text { mean_report_rate } \text { host }\right)
$$

With SSB_report host $_{\text {and }}$ aneference_report ${ }_{\text {host }}$, the density of Sphaeropsis shoot blight or reference report per host, mean_report_rate ${ }_{\text {host}}$, the ratio between the total number of Sphaeropsis shoot blight reports and the total number of reference reports for a particular host. All these analyses were done using the $R$ statistics software (R Foundation for Statistical Computing).

\section{Comparison of estimated past, present and future prevalence of $\mathbf{S}$. sapinea on cones}

The fitted model developed to explain prevalence of $S$. sapinea on cones was used to evaluate the potential impact of past and future climate on presence of $S$. sapinea inoculum in the stands. For past climate, we used the AURELHY data that are spatialized means over the 1961-1990 period for the monthly average temperature and rain provided by MétéoFrance. These spatialized data are computed for each point of a $1 \times 1 \mathrm{~km}$ grid over France by a method taking into account topography. For future data, we used data from ARPEGE, a global circulation model (Déqué et al., 1994). The model calculates relevant meteorological parameters on a grid of 360 points in France for the period 1960 to 2100 according to several scenarios of the evolution of atmosphere composition. The calculation of radiation includes the effect of four greenhouse gases $\left(\mathrm{CO}_{2}, \mathrm{CH}_{4}, \mathrm{~N}_{2} \mathrm{O}\right.$ and CFC) in addition to water vapour and ozone, and of five aerosol types (land, sea, urban, desert and sulphate) in addition to background aerosols. The model used was forced by an effective greenhouse effect corresponding to the provisional IPCC2001 B2 scenario (Garrett et al., 2006; DesprezLoustau et al., 2007). This $\mathrm{CO}_{2}$ emission scenario is mild; it was however kept to enable comparison with others projections made on the impact of climate change on French forest ecosystems.
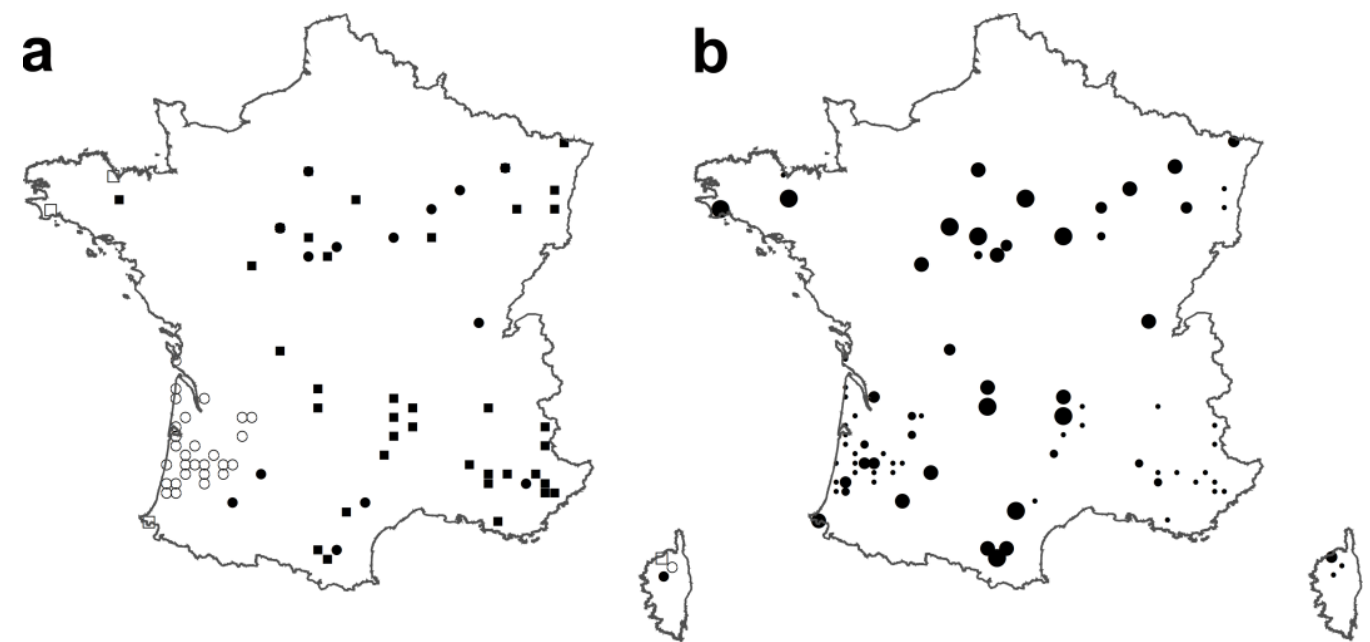

Fig. 1. Plots visited during the survey. A, pine species presence on plots, $\bullet, P$. nigra, $\circ$, $P$. pinaster, $\square, P$. radiata, $\mathbf{m}, P$. sylvestris. B, prevalence of Diplodia pinea on cones, , $0 \%, \bullet, 33 \%, \bullet, 66 \%, \bullet, 100 \%$.

To study whether the past and future evolution of climate could favour presence of $S$. sapinea in pine stands, maps of the pathogen prevalence on cones of $P$. nigra / P.sylvestris for the 1961-1990, 1991-2005 and 2030-2060 periods were derived from the previously developed logistic model fed with the various climatic datasets: the Aurelhy data (1961-90), the 1991-05 meteorological data used to initially develop the model and the ARPEGE data 
for the 2030-60 periods, adapting the anomaly method used by Bergot et al. (2004). Briefly, evolutions of the relevant meteorological parameters from the 1961-90 to the 1991-2005 period were computed for each of the available meteorological stations. Only the 109 meteorological stations with data available from 1961 to 2005 were used. Relevant meteorological parameters for the Aurelhy grid were computed by summing the 1961-90 Aurelhy data and the 1960-90 to 1990-2005 evolution at the nearest available meteorological station. The same technique was used to produce the 2030-60 map of $S$. sapinea prevalence on cones. The potential evolution in predicted $S$. sapinea prevalence on pine cones at the 109 meteorological stations with 1960-2005 data and at the 360 ARPEGE grid points with 1990-2060 data was tested by paired $t$-test.

\section{Results}

\section{S. sapinea prevalence on cones}

Strong heterogeneity was found in the colonization of cones by $S$. sapinea, with prevalence ranging from 0 to $100 \%$ of cones colonized per stand (Fig. $1 \mathrm{~b}$ ). The pathogen was detected on all studied pine species in all the country. A total of 300 fungal isolates were analysed for the species determination. The species found to be present most of the time was Diplodia pinea. $D$. scrobiculata was observed in only three cones in a single $P$. radiata stand in Corsica and these cones were also colonized by $D$. pinea. Thus, the study hereafter only refers to $D$. pinea.

Table 1. Odds ratio associated with the fitted multivariate model explaining prevalence of Diplodia pinea on pine cones in France.

\begin{tabular}{ccr}
\hline Factor & $\begin{array}{c}\text { Odds Ratio } \\
\text { (Confidence } \\
\text { limits) }\end{array}$ & P value \\
\hline Host species: $P$. sylvestris versus $P$. pinaster & $10.9(4.9-24.6)$ & $<0.001$ \\
P. nigra versus $P$. pinaster & $12.1(5.6-26.1)$ & $<0.001$ \\
P. radiata versus $P$. pinaster & $\mathrm{NS}$ & 0.397 \\
Mean minimum daily temperature in winter $\left(\right.$ per $\left.1^{\circ} \mathrm{C}\right)$ & $1.6(1.4-1.8)$ & $<0.001$ \\
Rain in summer (per $10 \mathrm{~mm})$ & $1.07(1.02-1.13)$ & 0.005 \\
\hline
\end{tabular}

NOTE: Model was fitted with scale factors of deviance / df value, the deviance / df of 2.0 indicating overdispersed data.

Three main factors explained the heterogeneity of cone colonization. Strong differences were found in the colonization of cones between the different pine species (Table 1, Fig. 3). $P$. nigra and $P$. sylvestris cones were colonized 11-12 fold more often than $P$. pinaster cones (Table 1). No significant difference in colonization between $P$. nigra and $P$. sylvestris cones was detected $\left(X^{2}=0.42, P=0.520\right)$. High winter temperature had a positive impact on the frequency of cone colonization by $D$. pinea: for each additional $1^{\circ} \mathrm{C}$ on the mean winter daily minimal temperature, cone colonization was multiplied by 1.6 (Table 1 , Fig.3b). This probably explains that cone colonization was inversely proportional to altitude (Fig. 3a), with a significant relationship $\left(x^{2}=16.81, P=0.001\right)$. Finally, rain in summer increased slightly but significantly the pathogen prevalence on cones (x 1.07 for each additional $10 \mathrm{~mm}$ of summer rain, Table 1 ).

By contrast, several factors were not linked with cone colonization by $D$. pinea, in particular pine age $\left(X^{2}=0.05, P=0.819\right)$. Stand origin, i.e. natural or artificial, was significantly linked to the level of pathogen presence on cones $\left(X^{2}=38.01, P=0.001\right)$. 
However, this was a spurious correlation linked to the fact that most natural stands were located at high elevation, in areas with cold winters and had cones poorly colonised. When introduced in a model already including winter mean of minimum daily temperatures, the stand origin was not significantly linked to the prevalence of $D$. pinea on cones $\left(x^{2}=0.13\right.$, $P=0.720$ ). Indeed, we noticed that cones in stands of natural origin in plains were usually heavily colonized.
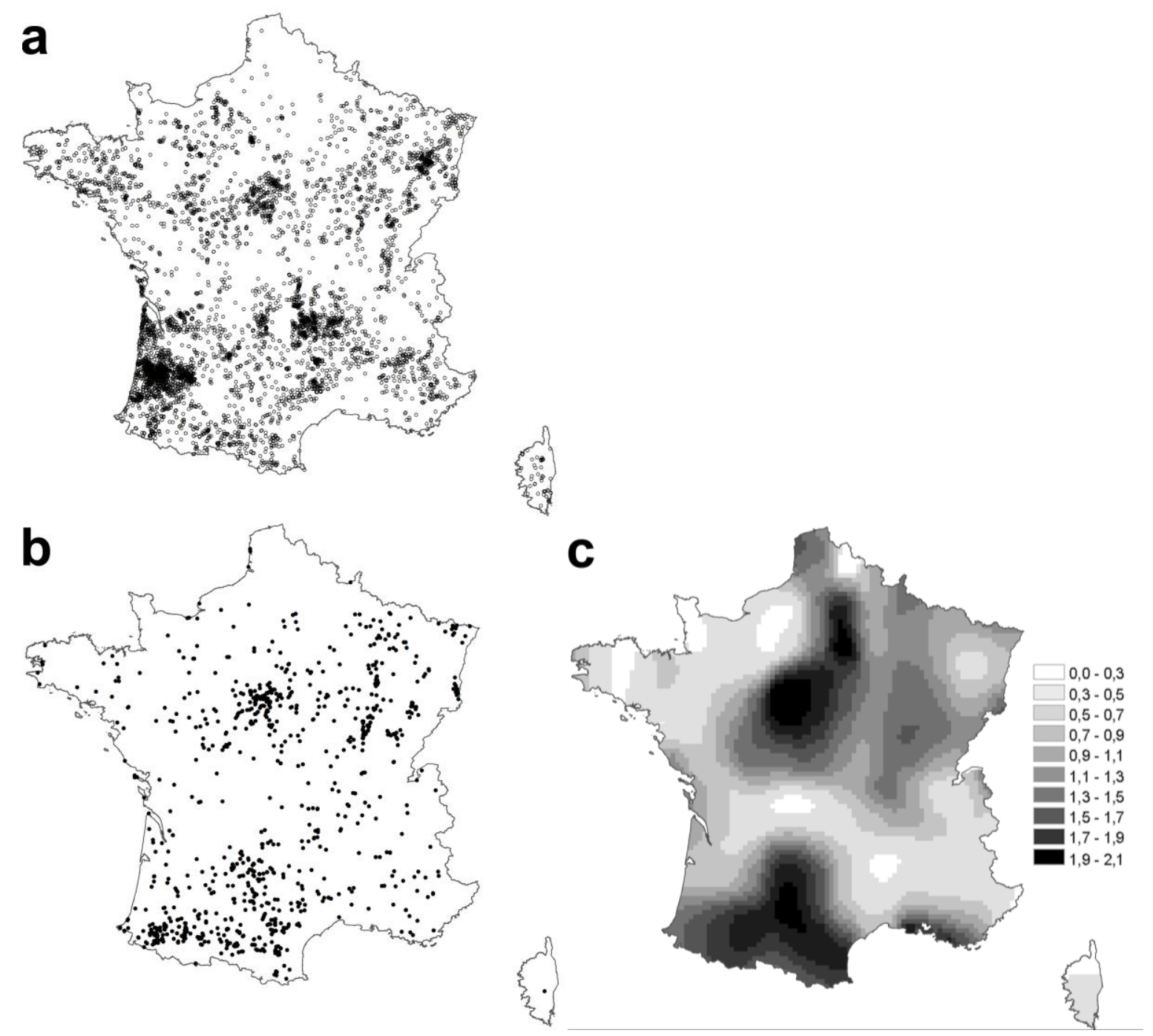

Fig. 2. Report of Sphaeropsis shoot blight in the DSF database (1989-06). a. reference report (o). b. Sphaeropsis shoot blight reports $(\bullet)$. c. standardised report rate.

Comparison between pattern of prevalence on cone and Sphaeropsis shoot blight report

Figure $2 \mathrm{~b}$ shows the spatial pattern of Sphaeropsis shoot blight report in the DSF database from 1989 to 2006. The report is especially high in SW and central France with SRR over one, while SRR in NW and mountain areas such the Alps and Massif Central are lower than one indicating Sphaeropsis shoot blight reports less frequent than average. This spatial pattern in SRR shows similarity with the spatial pattern in $D$. pinea prevalence on 
cones (compare Fig. 1b and Fig. 2b). The relationship is highly significant when comparing the $D$. pinea prevalence on cones measured in each surveyed plot with the estimated SRR at the location $(F=27.10$, pvalue $<0.0001)$. Figure 4 shows that the Sphaeropsis shoot blight $S R R$ increases with the observed $D$. pinea prevalence on cones.
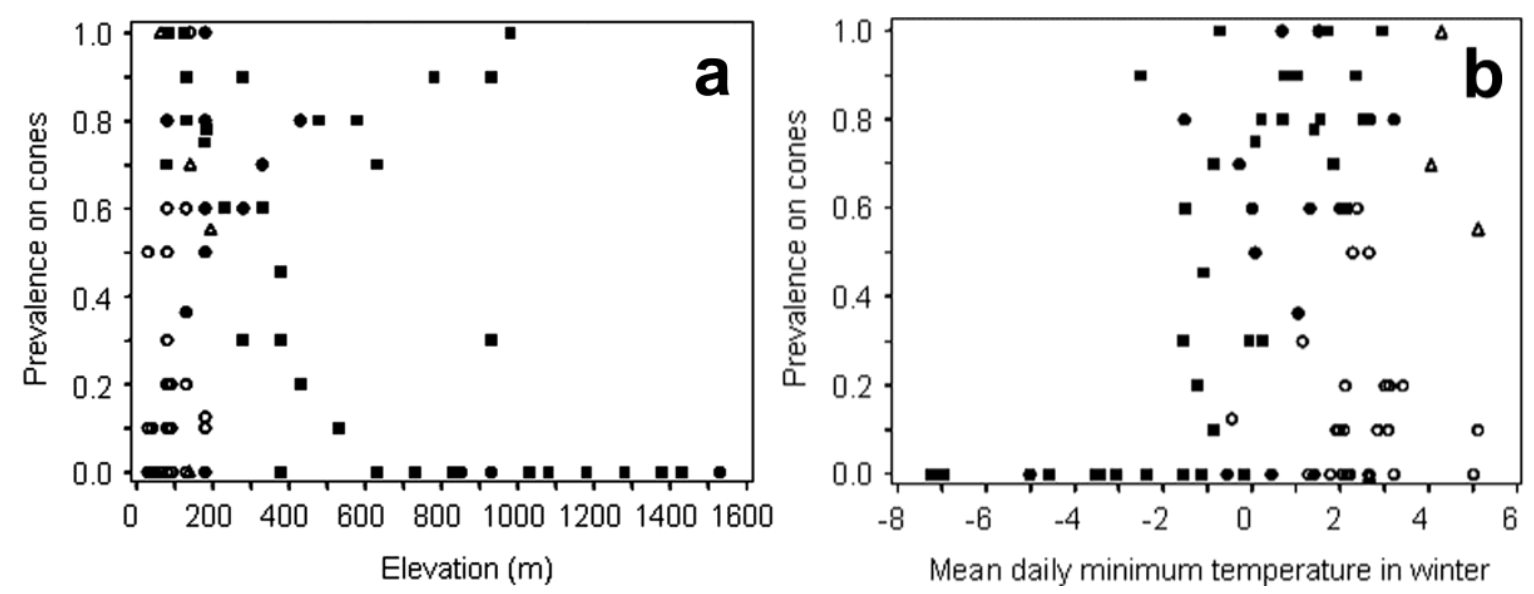

Fig. 3. Influence of elevation and temperature on cone colonization by Diplodia pinea. a. Elevation $\left(X^{2}=16.81, P=0.001\right)$; b. mean daily minimum temperature in winter (December to February, $X^{2}=31.05, P=0.001$ ). $\bullet$, $P$. nigra, $\circ, P$. pinaster, $\Delta$, $P$. radiata, $\mathbf{\square}, P$. sylvestris.

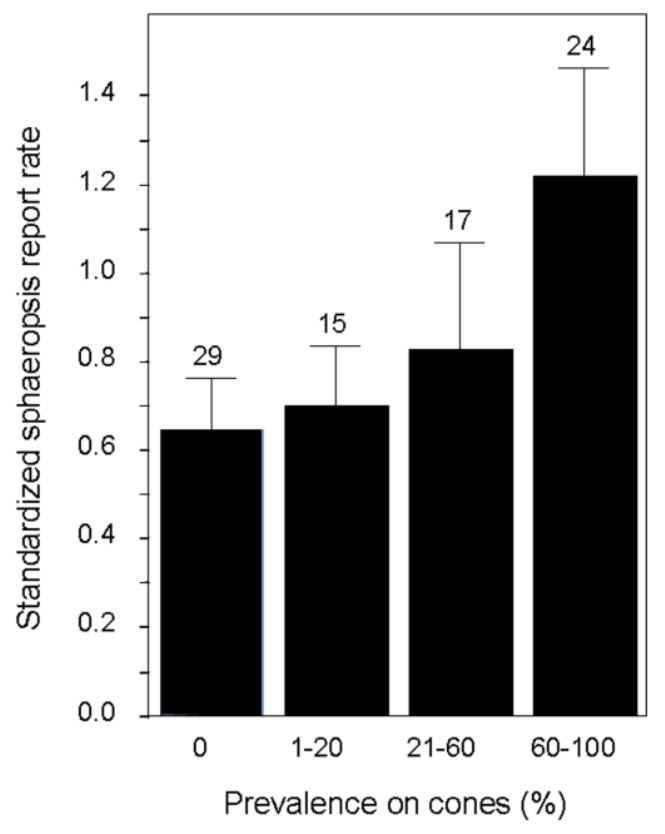

Fig. 4. Relationship between regional severity of Sphaeropsis shoot blight and prevalence of $D$. pinea on cones. The bars represent the confidence interval for the mean. 
We produced maps representing predicted colonization of $P$. nigra and $P$. sylvestris cones by $D$. pinea in France according to the model presented in Table 2, i.e. with winter temperature and summer rain, for three periods, 1961 to 1990,1990 to 2005 and 2030 to 2060. Compared to data used for model development, we extrapolated to dryer and hotter situations. However, the areas concern by this extrapolation are very limited Mediterranean and Atlantic costal regions (3.5\% of the area for the $2030-60$ period) and this has very little impact on the global prediction. The predicted prevalence of $D$. pinea on cones significantly increased from 1960-90 to 1990-2005. Indeed, the mean predicted prevalence at the 109 studied meteorological stations was multiplied by 1.14 between the two periods (paired $t$ test $=14.55, P<0.001$ ). The increase was mainly explained by an increase in the daily minimum temperature in winter $\left(+0.7^{\circ} \mathrm{C}\right)$ while the summer rain increased slightly $(+3.7$ $\mathrm{mm})$. The comparison of maps from Figures $5 \mathrm{a}$ and $5 \mathrm{~b}$ shows an eastward expansion of areas favourable to the presence of $D$. pinea in the pine stands, while the situation has not changed in mountain areas that remain unfavourable or on the Atlantic shore that remains favourable. When the predicted prevalences for the periods 1990 to 2005 and 2030 to 2060 were compared, the increase was also significant, but slighter, with prevalence multiplied by 1.05 (paired $t$-test $=16.86, P<0.001$ ). The impact on $D$. pinea prevalence on cones of the predicted increase in winter daily minimum temperature from $1990-2005$ to $2030-60\left(+0.7^{\circ} \mathrm{C}\right)$ was less significant because the 1990-2005 winter temperature levels are already favourable to $D$. pinea in most French low lands; the predicted increase in $D$. pinea prevalence on cones of the increase was also slightly mitigated by a predicted decrease in summer rain (- 23.0 $\mathrm{mm})$.

\section{Discussion}

We found that the most frequent Diplodia species present in pine stands in France is $D$. pinea. The data are consistent with the hypothesis that recent climate warming might have contributed to the emergence of Sphaeropsis shoot blight in France by a direct positive impact on the pathogen. Indeed, spatial pattern of $D$. pinea frequency in stands and Sphaeropsis shoot blight report by the forest health survey system (DSF) were correlated. Frequency of $D$. pinea in pines stands was mainly explained by the host species and by climate, especially high winter temperature. The climate became more favourable to $D$. pinea presence in pines stands within the last 15 years compared to the previous 30 years period. By contrast, future climatic changes over the next 40 years as predicted by Météo-France should have far less impact on the pathogen frequency on cones.

Diplodia pinea was the only species found on the cones of Pinus pinaster, $P$. sylvestris, and $P$. nigra collected on the soil. Thus, French pine stands are exposed to the aggressive $D$. pinea species which has often been associated with induction of twig necrosis while D. scrobiculata is less aggressive (Palmer et al., 1987, Bihon et al., 2010). The distribution of $D$. scrobiculata within France, only found on $P$. radiata in Corsica, is interesting. Indeed, the pathogen has yet been reported in Europe sporadically in mediteranean areas (Morelet \& Chandelier, 1993), in South Africa (Bihon et al., 2010) and is the only species found on the native $P$. radiata in California (Burgess et al, 2001). However, the limited distribution of $D$. scrobiculata in France cannot be explained only by host preference as, although only $D$. pinea is reported from $P$. pinaster and $P$. nigra, both $D$. pinea and $D$. scrobiculata have been observed on P. sylvestris and P. radiata (Stanosz et al., 1999; de Wet et al., 2003). In view of the very limited distribution of $D$. scrobiculata in France, the hypothesis that the replacement of this species by the more aggressive $D$. pinea could have caused the emergence of the Diplodia shoot blight in France in the early nineties is not likely. Indeed, althougth the two pathogens were always found competing on the same cones, the complete elimination of $D$. scrobiculata from most of French pine stands through competition with $D$. pinea would be surprising as the two pathogens coexists in pines stands of the central part of USA (Palmer et al, 1987). However, we cannot rule out this hypothesis. 

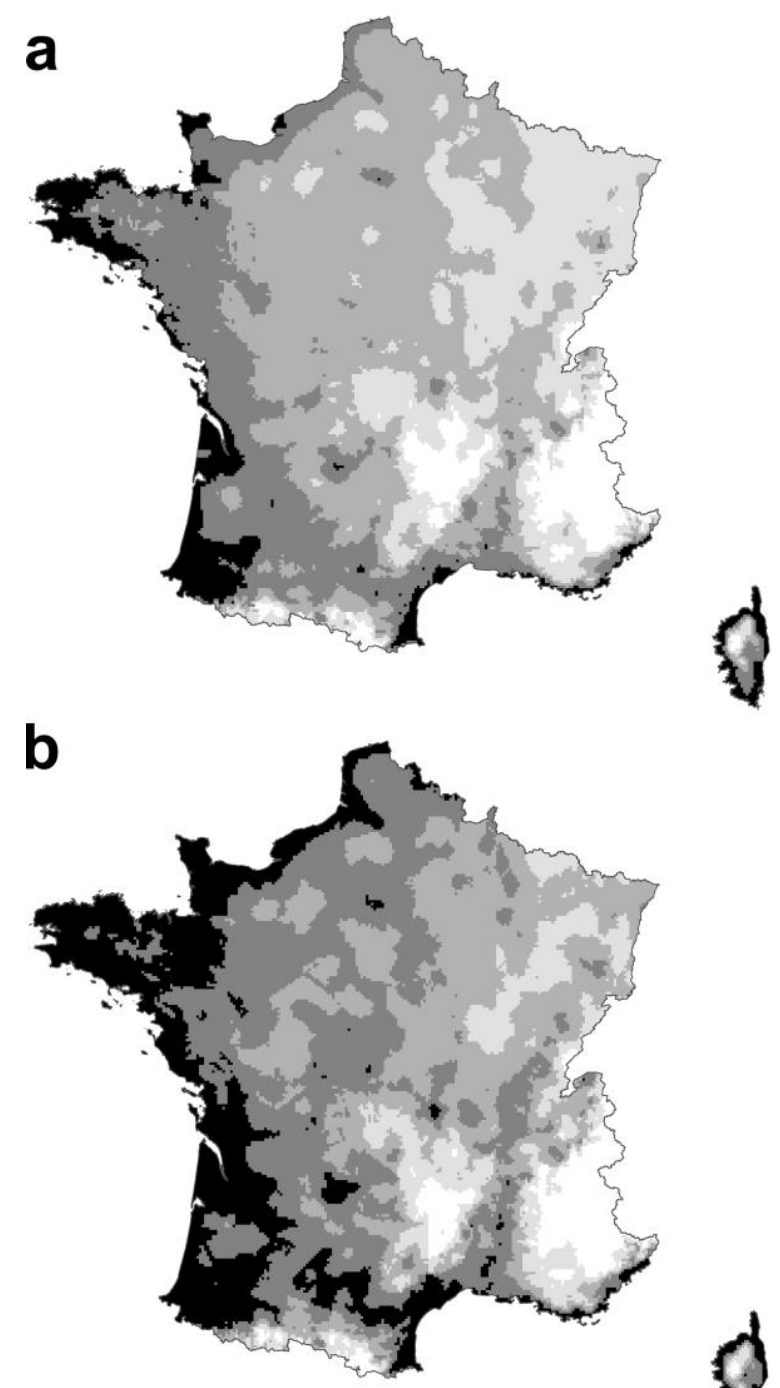

Fig. 5. Maps of cone colonization in France by Diplodia pinea for $P$. nigra and $P$. sylvestris predicted by the fitted model for periods: a. $1960-1990$, b. 1990 to 2005, c. 2030 to 2060. The fitted model is: Logit $(p)=-1.83+0.007 \times$ Rain $_{\text {sum }}+0.45 \times \mathrm{Tn}_{\text {win }}$, with $p$, the proportion of colonized pine cones, Rain ${ }_{\text {sum }}$ the annual rain in June-August and $\mathrm{Tn}_{\text {win }}$ the mean daily minimum temperature in December-February. $\square, 0-20 \%, \square, 20$ $40 \%, \square, 40-60 \%, \square, 60-80 \%, \square, 80-100 \%$.

We documented a positive relationship between regional Sphaeropsis shoot blight report by the DSF and $D$. pinea frequency on cones in studied stands. This result is not easy to interpret in terms of causal relationships. On the one hand, it has been reported that severe Sphaeropsis shoot blight is conditioned by high inoculum level from cones (Palmer et al. 1988), but on the other hand, an increase in inoculum in areas favourable to disease expression cannot be ruled out. However, our data show that significant disease levels are not a prerequisite for high colonisation rate of cones: a high frequency of $D$. pinea on cones together with low local report of Sphaeropsis shoot blight was observed in some areas (Massif Central, Brittany in the NW). Indeed, climatic conditions favourable for cones colonisation and for Sphaeropsis shoot blight are different. If high temperatures are needed for both, strong cone colonisation by $D$. pinea was related to high summer rainfall will severe Sphaeropsis shoot blight is known to be associated with drought (Bachi \& Peterson, 1985; Blodgett et al., 1997). The importance of drought for disease occurrence explains the 
variability in regional Sphaeropsis shoot blight standardized report at a given level of cone colonization.

One of the main factors explaining the prevalence of $D$. pinea on the cones was the host species. Although $P$ sylvestris has been reported to be less susceptible to $D$. pinea than $P$. nigra (Vujanovic et al., 2000), this was not paralleled by a higher presence of the pathogen on the cones of this species. By contrast, $P$. pinaster cones were less frequently colonized by $D$. pinea than cones of other pines species. The low frequency of $D$. pinea in the Landes area, in south-western France on $P$. pinaster cones cannot be explained by an unfavourable climate as the area is submitted to mild winter temperature and high rainfall. This low inoculum level in the P. pinaster stands of SW France parallels low Sphaeropsis shoot blight report in the area. This cannot be explained by resistance of $P$. pinaster to Sphaeropsis shoot blight as this species showed moderate to high susceptibility to $D$. pinea when tested in artificial inoculation (Swart et al., 1988). Alternative hypotheses are that either $D$. pinea has a poor ability to colonise $P$. pinaster cones or that the area has not yet been colonised by the pathogen for historical reason. A possibility could be that until the last decades, $P$. pinaster stands in the Landes area were installed by sowing and not by planting nursery seedling that are known to be possible sources of $D$. pinea inoculum (Palmer et al., 1988).

Both winter temperature and summer rainfall explained the local prevalence of $D$. pinea on pines cones. The positive effect of winter temperature can be explained by the high thermal requirements of the fungus (about $30^{\circ} \mathrm{C}$ for optimal growth, Keen \& Smits $1989,8^{\circ} \mathrm{C}$ as a minimal threshold for growth, Desprez-Loustau et al 2007). The low prevalence on cones in areas of low winter temperature probably explains the decreased presence of the pathogen at high elevation, which has already been mentioned in the literature (Zwolinski et al., 1990). The low impact of $D$. pinea at high elevation might be caused by low presence of inoculum in the stands more than to conditions not conducive to disease expression. Indeed, the pine species present in the mountain areas, $P$. nigra and $P$. sylvestris are susceptible hosts the cones of which are usually well colonized. High rain in summer has already been mentioned in literature to be favourable to development of $D$. pinea. Indeed, Peterson (1977) showed that the pathogen extensively develops pycnidia on second-year seed cones and needles in the autumn if late summer rain is abundant.

The fitted model linking the pathogen presence in the stands to climate allowed us to produce a map of the French current situation but also to simulate maps of the past and future situations. Clearly, climate became more favourable to the pathogen presence in the stands in the last 15 years compared to the 1960-90 period. This evolution of the climate could at least partly explain the emergence of the disease in the $90^{\text {ies }}$ in France. Indeed, especially in central France where the disease was severe during the last outbreaks (Piou et al., 1991), the French climatic conditions were far less favourable to the pathogen development in the 1960-90 period than in the current period. By contrast, the simulated future evolution according to our model showed limited increase of $D$. pinea presence over France. In particular, mountain areas are predicted to remain unfavourable to the pathogen. This may be explained because most of climate constraints on pathogen presence were relieved in the recent decade in the lowland area of France and only the mountain areas remain unfavourable to the pathogen presence on cones. Future increase in temperature thus relieve constraints on pathogen presence in area of limited surface at the periphery of mountains. Also, it has to be pointed out that the $\mathrm{B} 2 \mathrm{CO}_{2}$ emission scenario that we used is mild which could explain this moderate projected evolution. However, projections made on other tree diseases or on tree species distribution under the B2 emission scenario often showed large increases in the species presence (Bergot et al 2004; Badeau et al, 2010).

Few studies explore the impact of climate changing on plant diseases and even fewer demonstrated a causal relationship between climate change and the recent emergence of plant diseases (Garrett et al., 2006) although some cases were documented for forest diseases (Wood et al., 2005). Most of the studies only consider the impact of increasing 
temperature, improving either overwintering or pathogen population increase during the vegetation season. This approach was used to model the epidemics of oak disease caused by Phytophthora cinnamomi in Europe under climate change (Bergot et al., 2004; Brasier et al., 1994). It was shown that climate warming could allow the disease expansion of one to a few hundred kilometres eastward from the Atlantic coast within one century. The originality of our study is that both changes in temperature and precipitation were taken into account in the model. Host-pathogen interactions are complex and climatological factors vary simultaneously in a dynamic environment. Few studies have been done to model effects of climate change with several environmental factors. For example, Evans et al. (2008) developed models based on temperature, precipitation and elevated $\mathrm{CO}_{2}$ and proved the increasing potential for phoma stem canker, caused by Leptosphaeria maculans under global warming. Desprez-Loustau et al. (2007) showed that for foliar forest diseases such as Dothistroma needle blight, the increase in temperature could be balanced by a reduction in precipitation mitigating the impact of climate change on the disease. The model developed in this work takes into account only direct impact of climate change on pathogen presence in stands. However, there is a need for more completes models taking into account the impact of water shortage on the host tree physiology. Indeed, although climate evolution might not be more favourable to pathogen presence on cones, the predicted increases in the frequency and severity of drought should favour Sphaeropsis shoot blight outbreaks.

\section{Acknowledgements}

We thank Michael J. Wingfield and Juanita de Wet to provide us the Diplodia isolates CMW190 and CMW4898 used in this study. Olivier Caël and Xavier Capdevielle were of great technical help for field works and Axelle Andrieux for the molecular determination of the isolates. This work was founded by the Forest Focus EU program and by the Emerfundis Agence national de la Recherche program.

\section{References}

Anderson PK, Cunningham AA, Patel NG, Morales FJ, Epstein PR, Daszak P (2004) Emerging infectious diseases of plants: pathogen pollution, climate change and agrotechnology drivers. Trends in Ecology \& Evolution 19, 535-544.

Bachi PR, Peterson JL (1985) Enhancement of Sphaeropsis sapinea stem invasion of pines by water deficits. Plant Disease 69, 798-799.

Badeau V, Dupouey JL, Cluzeau C, Drapier J, Bas C le (2010) Climate change and the biogeography of French tree species: first result and perspectives. . In: Forests, carbon cycle and climate change , Ed D. Loustau, pp 231-252

Bihon W, Slippers B, Burgess T, Wingfield BD, Wingfied MJ (2010) Diplodia scrobiculata found in the southern hemisphere. Forest Pathology Doi 10.1111/j.1439-0329.2010.00649.x

Bergot M, Cloppet E, Pérarnaud V, Déqué M, Marçais B, Desprez-Loustau M-L (2004) Simulation of potential range expansion of oak disease caused by Phytophthora cinnamomi under climate change. Global Change Biology 10, 1539-1552.

Blodgett JT, Kruger EL, Stanosz GR (1997) Effects of moderate water stress on disease development by Sphaeropsis sapinea on red pine. Phytopathology 87, 422-428.

Brasier CM, and Scott JK (1994) European Oak declines and global warming: a theoretical assessment with special reference to the activity of Phytophthora cinnamomi. Bulletin OEPP / EPPO Bulletin 24, 221-232.

Browder LE, Eversmeyer MG (1986) Interactions of temperature and time with some Puccinia recondita:Triticum corresponding gene pairs. Phytopathology 76, 1286-1288.

Burgess T, Wingfield BD, Wingfield MJ (2001) Comparison of genotypic diversity in native and introduced populations of Sphaeropsis sapinea isolated from Pinus radiata. Mycological Research 105, 1331-1339. 
Burgess TI, Wingfield MJ, Wingfield BD. 2004. Global distribution of Diplodia pinea genotypes revealed using simple sequence repeat (SSR) markers. Australasian Plant Pathology 33, 513519.

Collet D (1991) Modelling Binary Data. London, UK: Chapman and Hall.

de Kam M (1985) Sphaeropsis (= Diplodia) shoot dieback: an incident or a permanent problem? Nederlands Bosbouwtijdschrift 57, 118-122.

de Wet J, Burgess T, Slippers B, Preisig O, Wingfield BD, Wingfield MJ (2003) Multiple gene genealogies and microsatellite markers reflect relationships between morphotypes of Sphaeropsis sapinea and distinguish a new species of Diplodia. Mycological Research 107, 557-566.

Déqué M, Dreveton C, Braun A, Cariolle D (1994) The ARPEGE/IFS atmosphere model: a contribution to the French community climate modelling. Climate Dynamics 10, 249-266.

Desprez-Loustau ML, Marçais B, Nageleisen LM, Piou D, Vannini A (2006). Interactive effects of drought and pathogens on forest trees. Annals of Forest Sciences 63, 597-612

Desprez-Loustau ML, Robin C, Reynaud G, Deque M, Badeau V, Piou D, Husson C, Marcais B (2007) Simulating the effects of a climate-change scenario on the geographical range and activity of forest-pathogenic fungi. Canadian Journal of Plant Pathology 29, 101-120.

Evans N, Baierl A, Semenov MA, Gladders P, Fitt BDL (2008) Range and severity of a plant disease increased by global warming. Journal of The Royal Society Interface 5, 525-531.

Fecci E, Battisti A, Capretti P, Tegli S (2002) An association between the fungus Sphaeropsis sapinea and the cone bug Gastrodes grossipes in cones of Pinus nigra in Italy. Forest Pathology 32, 241-247.

Garrett KA, Dendy SP, Frank EE, Rouse MN, Travers SE (2006) Climate change effects on plant disease: genomes to ecosystems. Annual Review of Phytopathology 44, 489-509.

Harvell CD, Mitchell CE, Ward JR, Altizer S, Dobson AP, Ostfeld RS, Samuel MD (2002) Climate warming and disease risks for terrestrial and marine biota. Science 296, 2158-2162.

Keen A, Smits TFC (1989) Application of a mathematical for a temperature optimum curve to establish differences in growth between isolates of a fungus. Nertherland Journal Plant. Pathology 95, 3749.

Lanier L, Joly P, Bondoux P, Bellemère A (1976) Pathologie des essences résineuses. In : Mycologie et Pathologie forestières, II Pathologie forestière, ed. Masson, Paris

Lawson AB (2006) Statistical methods in spatial epidemiology. Wiley series in probability and statistics, $2^{\text {nd }}$ edition, 398 pages.

Marçais B, Dupuis F, Desprez-Loustau M-L (1996) Modelling the influence of winter frosts on the development of the ink disease of oak, caused by Phytophthora cinnamomi rands. Annales des Sciences Forestières. 53, 369-382.

Morelet M (1980) La maladie à Brunchorstia II repartition en France. European Journal of Forest Pathology. 10, 354-359.

Morelet M, Chandelier P (1993) A case of variability in Sphaeropsis sapinea. European Journal of Forest Pathology 23, 317-320.

Munck IA, Stanosz GR (2010) Longevity of inoculum production by Diplodia pinea on red pine cones. European Journal of Forest Pathology 40, 58-63

Nicholls TH, Ostry ME (1990) Sphaeropsis sapinea cankers on stressed red and jack pines in Minnesota and Wisconsin. Plant Disease 74, 54-56.

Palmer MA, Stewart EL, Wingfield MJ (1987) Variation among isolates of Sphaeropsis sapinea in the north central United States. Phytopathology 77, 944-948.

Palmer MA, McRoberts RE, Nicholls TH (1988) Sources of inoculum of Sphaeropsis sapinea in forest tree nurseries. Phytopathology 78, 831-835.

Peterson GW (1977) Infection, epidemiology, and control of Diplodia blight of Austrian ponderosa and Scots pines. Phytopathology 67, 511-514.

Piou D, Chandelier P, Morelet M (1991) Sphaeropsis sapinea [Diplodia pinea], a new health problem of pines in France? Revue Forestiere Francaise 43, 203-213.

Smith DR, Stanosz GR (2006) A species-specific PCR assay for detection of Diplodia pinea and D. scrobiculata in dead red and jack pines with collar rot symptoms. Plant Disease 90, 307-313. 
Stanosz GR, Swart WJ, Smith DR (1999) RAPD marker and isozyme characterization of Sphaeropsis sapinea from diverse coniferous hosts and locations. Mycological Research 103, 1193-1202.

Stanosz GR, Trobaugh J, Guthmiller MA, Stanosz JC (2004) Sphaeropsis shoot blight and altered nutrition in red pine plantations treated with paper mill waste sludge. Forest Pathology 34, 245253.

Sturrock RN, Frankel SJ, Brown AV, Hennon PE, Kliejunas JT, Lewis KJ, Worrall JJ, Woods AJ (2011). Climate change and forest diseases. Plant Pathology 60, 133-149

Swart WJ, Wingfield MJ, Knox-Davies PS (1988) Relative susceptibility to Sphaeropsis sapinea of six Pinus spp. cultivated in South Africa. European Journal of Forest Pathology 18: 184-189.

van Dijk HFG, van der Gaag M, Perik PJM, Roelofs JGM (1992) Nutrient availability in Corsican pine stands in the Netherlands and the occurrence of Sphaeropsis sapinea: a field study. Canadian Journal of Botany 70, 870-875.

van Staden V, Erasmus BFN, Roux J, Wingfield MJ, van Jaarsveld AS (2004) Modelling the spatial distribution of two important South African plantation forestry pathogens. Forest Ecology and Management 187, 61-73.

Vujanovic V, St-Arnaud M, Neumann PJ (2000) Susceptibility of cones and seeds to fungal infection in a pine (Pinus spp.) collection. Forest Pathology 30, 305-320.

Wand MP, Jones MC (1995) Kernel smoothing. Monographs on Statistics and Applied Probability, Chapman and Hall.

Woods A, Coates KD, Hamann A (2005) Is an Unprecedented Dothistroma Needle Blight Epidemic Related to Climate Change? BioScience 9, 761-769

Zwolinski JB, Swart WJ, Wingfield MJ (1990) Intensity of dieback induced by Sphaeropsis sapinea in relation to site conditions. European Journal of Forest Pathology 20, 167-174. 